\title{
Greek into Arabic. Philosophical Concepts and Linguistic Bridges
}

\author{
Cristina D’Ancona, Gerhard Endress, Andrea Bozzi*
}

\section{General aims}

Hosted by the Università di Pisa as the Host Institution, with the Ruhr-Universität Bochum and the Istituto di Linguistica Computazionale of the Italian Consiglio Nazionale delle Ricerche as Associate Participants, "Greek into Arabic « was a five-year project funded by the European Research Council (Greek into Arabic. Philosophical Concepts and Linguistic Bridges ERC AG 249431). ${ }^{1}$ The transmission of philosophical thought from Greek classical and post-classical Antiquity to the Arabic-speaking world was at its core. The translations ${ }^{2}$ that allowed a cultivated Arabic elite to get acquainted with Greek philosophy and science between the 8th and the 10th cent. AD have been investigated from three interconnected viewpoints: (i) the in-depth analysis of a specific work emblematic of this transmission, (ii) the lexicographical issues involved in the process of inculturation of the Greek heritage, and (iii) the development of a specific tool in the field of computational linguistics. The synergy of philologists and historians of philosophy, lexicographers, and computational linguists was meant to reach a threefold goal: (i) the critical edition of the so-called Theology of Aristotle, (ii) the completion of the Glossarium Graeco-Arabicum, and (iii) the creation of a system for the alignment and analysis of Greek philosophical works and their Arabic medieval translations. While the first goal is still on its way to being achieved, the Glossarium GraecoArabicum has been completed, and the computational linguistics system has been created under the label $G 2 A$.

\section{The so-called Theology of Aristotle}

A pivotal text for medieval Arabic philosophical literature, the text entitled Theology of Aristotle in the manuscripts and alluded to under this heading by the Arab writers of the classical and post-classical age, is poorly edited: the two extant editions are based on few and random manuscripts. As the first step towards the critical edition, "Greek into Arabic « was engaged from the outset in searching for the manuscripts of this work in the libraries of various

* Correspondence details: Cristina D’Ancona, Dipartimento di Civiltà e Forme del Sapere, via P. Paoli 15, 56126 Pisa, Italy, Email: cristina.dancona@unipi.it.

Gerhard Endress, Seminar für Orientalistik Ruhr-Universität Bochum, Fakultät für Philologie, Gebäude GB 2/135, D-44780 Bochum, Germany, Email: gerhard.endress@ruhr-uni-bochum.de.

Andrea Bozzi, CNR- Istituto di Linguistica Computazionale A. Zampolli, Area della Ricerca del CNR di Pisa, via G. Moruzzi 1, 56124 Pisa, Italy, Email: bozzilcan@gmail.com.

Duration: 2010-2015; for further information on the project and the team members please consult the project website: www.greekintoarabic.eu.

2 Endress, Die wissenschaftliche Literatur; D’Ancona, Greek into Arabic; D'Ancona, Greek Sources in Arabic and Islamic Philosophy. 
non-European countries (Egypt, Syria, Turkey, Iran, Iraq, Uzbekistan, and India). The missions conducted under the aegis of "Greek into Arabic « raised the number of the manuscripts from the two that were known to the editor of the princeps $\mathrm{F}$. Dieterici ${ }^{3}$ and the eight known to the 20th-century editor 'A. Badawi ${ }^{4}$ to the 95 known at present. This number will, in all likelihood, increase after examination in situ of the libraries of Calcutta, Hyderabad, Patna and Rampur, something that proved not to be possible during the lifetime of the project, because visits to these libraries have been hampered by a lack of cooperation on the part of the local staff. In contrast, in the countries where our missions were welcomed, and chiefly in Iran, they were exceptionally fruitful: we discovered many manuscripts of the Theology that were previously unknown. This means that in all likelihood the real number of the manuscripts of the Theology exceeds 100.

A short account of what the Theology of Aristotle is and why it was so important is in order now. It goes without saying that the high number of manuscripts speaks for its importance, but also the fact that towering figures like Avicenna commented upon it, is telling. The influence of the Theology of Aristotle was pervasive in the works of most of the main

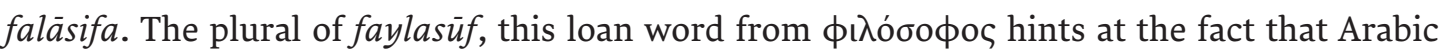
philosophy was (and was perceived as) rooted in the Greek works translated. The latter form the core of "Greek into Arabic « and the Theology of Aristotle is a case in point, as a blatant example of an inculturation that went as far as transforming Aristotle into the faylasü $f$ who, albeit unaware of any prophetic revelation, championed the main tenet of the Muslim faith: the divine Oneness (tawhìd).

The Theology is obviously not by Aristotle, even though it circulated under his name: rather, it is a heavily adapted translation of parts of Plotinus' Enneads, created no later than in the '40s of the 9th cent., when the philosopher al-Kindi " corrected « for his pupil Ahmad, the son of the caliph al- Mu'tașim (r. 833-842), a text translated from Greek that allegedly contained the "Theology « by Aristotle. Instead, selected parts from Enneads IV (on the soul), V (on the intelligible world) and VI (in the One) were translated and adapted. Thus, the "Theology « was meant to expound "Aristotle's « doctrine of the causality of the unique First Cause, and the degrees of the hierarchy of principles beneath it: the Intellect, and the cosmic soul. As such, the Theology counts as the most important example of that cross-pollination of Aristotelianism and Neoplatonism that is in many respects the hallmark of Arabic-Islamic philosophy in its classical age. The Neoplatonic One and the Aristotelian Unmoved Mover were merged together and presented as the philosophical counterpart of the unique God of the revealed Qur'ān. ${ }^{5}$

Our main endeavour at the beginning of the project was to organize missions in search of the manuscripts. The first mission to Iran (Tehran and Mashhad) resulted in obtaining reproductions of twenty-seven manuscripts. The mission to Turkey (Istanbul and Ankara) enabled us to obtain reproductions of all the manuscripts of the Theology housed there. We also got reproductions of the two manuscripts housed in Damascus, and of all of the manuscripts housed in Cairo. We were also able to obtain reproductions of manuscripts from Najjaf (Iraq) and Tashkhent (Uzbekistan). A second mission to Iran resulted in acquiring reproductions of nine manuscripts. Each of these missions revealed the existence of manuscripts that were 
unknown to us before, thereby prompting us to organize new missions both to Tehran and to other places in the country (Mashhad, Qom, Isfahan, Shiraz, Kashan, and Yazd). A third mission to Iran yielded reproductions of twenty-three further manuscripts. Together with the manuscripts of the Theology, several other works of the Graeco-Arabic tradition of philosophy and science have been reproduced and at present form a digital archive that has already been put into the service of the scholars working in the field.

All 95 manuscripts of the Theology and related materials that have been acquired thanks to these missions have been examined in detail in order to reach a first assessment of their date, provenance, and circulation. Very few of them date from the 15th and 16th centuries, while the great majority dates from the 17th century, and some from the 18th century. Taking into account that most manuscripts are of Persian origin and still belong to collections of Iranian libraries, one must conclude that the main spread of the Theology was in Persia during the Safavid age. The prosopographical information, the historical study of the circumstances in which the Safavid and Qajar copies of the Theology were commissioned and accomplished, and, finally, the inventory of the other texts associated with the Theology in the manuscripts shed light on the influence of this work and, more generally, of Graeco-Arabic philosophy in Persia. $^{6}$

This historical research was accompanied by the collation, and the very success of the missions resulted in a reiterative questioning of the provisional stemma codicum as the new entries were examined. Together with the high number of manuscripts, this accounts for the fact that the critical text is still in the process of being established. Notwithstanding this, some facts have been ascertained that can be summarized as follows: 1 . The textual tradition of the Theology is unitary, i.e. all the extant manuscripts derive from one single archetype, now lost, that was in itself marred by a number of errors shared by all of them. 2 . The textual tradition is bipartite: two main families have been detected, one of them formed by the great majority of the manuscripts, and the other formed by only five of them. The variant readings of both families are necessary for the establishment of the text. 3. All the Iranian manuscripts belong to the more numerous family. 4. Of the five manuscripts of the small family, two that are the most ancient testimonies of the entire textual tradition were in all likelihood copied at the court of Mehmed II (r. 1451-1481).

The critical edition is accompanied by a volume of Prolegomena, with essays on the transmission of the Enneads from Rome to Baghdad, on the Arabic translation, its milieu and technique, on the adaptations that transformed the Arabic Plotinus into the Theology of Aristotle, on the other texts issued from the Arabic version of the Enneads, on the reception of the Theology by al-Fārābī, the Ismaili authors, Avicenna, al-Suhrawardī and other postAvicennian thinkers, as well as on the Latin version of the Theology during the Renaissance, and finally on its revival in Safavid Persia. 


\section{The Glossarium Graeco-Arabicum}

Another path to the study of the translations from Greek into Arabic, and a very important one, is represented by lexicography. The Greek and Arabic Lexicon in the form of a reference dictionary of the Arabic translations of Greek philosophical and scientific source texts has been the starting point and material basis of research activities at the Ruhr-University of Bochum. Within the context of "Greek into Arabic" the process of transformation of the reference dictionary Greek and Arabic Lexicon into a new tool, the Glossarium GraecoArabicum, was successfully completed.

The Glossarium Graeco-Arabicum database has not only taken over where the printed publication left off, but is complementing the material presented here and enhancing accessibility to a wider range of lexical, grammatical and stylistic features of scientific language. In the first instance, the database was created for presenting the basic data compiled in our card files and additional material collected by the Bochum team. For this purpose, the full card file was digitized, and for each entry, searchable data were entered from the file cards, after having been checked and supplemented on the basis of the original source texts. The software platform was developed as an online mySQL database, and continues to be hosted by the TELOTA centre of the Berlin-Brandenburg Academy of Sciences, url: telota.bbaw.de/ glossga. Since the start of "Greek into Arabic«, the principal development work has been the setting up of the database, programming the user interface and creating and enhancing sophisticated query, input and output facilities, accompanied by the data input.7 The database is meant to open up the full range of the terminology, and more generally, the grammar and style of scientific Arabic: registering the entire vocabulary of a total of 70 scientific and philosophical works dating from the 8th to the 10th centuries, a total of 95,500 records, thus documenting the language of scientific categorization and demonstrative discourse created by the translators and their Arabic readers. The authors of the 70 works mentioned above often used Arabic words in meanings different from those known from other branches of Arabic literature; they even coined their own derivatives and neologisms. In order to assess the precise meaning of each word, it is thus reasonable and methodologically sound to work on these texts by means of comparative lexicography. Our database is structured in the form of a bilingual reference dictionary and thus may also be used as a linguistic research tool for the investigation of the medieval translation movement from Greek into Arabic, as well as for the source analysis of the Arabic-Islamic sciences and philosophy building upon the translations. The task we set for ourselves was to make our materials, compiled in the earlier as well as in the more recent phase of our project, accessible in a searchable database. Further texts, edited recently and parsed in view of the Greek and Arabic correspondences, have been included. For many of the sources, the basic lexemes were supplemented by the relevant context and by comments regarding the translators' techniques and transposition.

All fields of the datasets are searchable through a database search engine. During the final period, our work has focused on the development of appropriate tools and techniques for visualization of the results of the search queries and on the creation of a user-friendly export function which provides the possibility to download or transfer via e-mail the results of any search query and the output of large subsets of data in the shape of lexical entries to be used for the continuation of the Greek and Arabic Lexicon as a printed work. ${ }^{8}$

8 Endress et al., Griechische Wissenschaft in arabischer Sprache. 


\section{The Research Infrastructure G2A}

This part of "Greek into Arabic « was devoted to the creation of a system for the alignment and analysis of translations. The system G2A, url: g2a.ilc.cnr.it:8080/Teologia_Wapp/ ViewByGreek.xhtml, is a research infrastructure designed to help scholars in the management of texts and translations. It has been created in line with the principles of the Research Infrastructures for Social Sciences and Humanities in order to meet the needs of a scholarly community interested in the transmission of philosophical and scientific texts from Greek into Arabic. As such, G2A pays special attention to the different structure of the sentences in both languages. Being aware of the mismatch that this difference in structure may generate, the ILC-CNR team has created a system that allows the Greek text and its Arabic version to be always aligned to each other, irrespective of the changes that may occur in the translated sentence. Another crucial point is that these changes have been carefully classified, taking into account the fact that some of the translations from Greek into Arabic are heavily adapted. This means that the differences between the original Greek sentence and its Arabic version are not limited to the different syntactical structure of the two languages, but can involve intentional changes. $G 2 A$ has been designed to deal with a particularly difficult issue, because in the process of the creation of the Theology of Aristotle out of the Arabic version of the Enneads blocks of text were moved to a different place with respect to the original flow of the Greek. To deal with this difficulty, a module has been designed that is capable of aligning the Greek and Arabic texts even when the original flow of the text has been altered. Segmentation into semantically corresponding portions was the starting point for producing aligned sentences. The specialists in the field determined the exact boundaries of the Arabic contexts that provide, in literal or interpretive form, the corresponding contexts of the Arabic version. The interface has been designed in order to have the pericopes realigned, should the specialist consider it necessary. To this end, a specific module, "Pericope Boundaries Editor ", has been implemented: it allows the specialist to change the borders of the pericopes. Another important feature to which attention has been paid, is to allow the user to follow the original flow of the Greek text and see the corresponding Arabic translation or, vice versa, to follow the flow of the Arabic text and scroll the original Greek sentences. G2A also envisions the possibility of a synthetic evaluation of the translation of a given sentence by means of annotations. Having provided the specialists with a tool to organize their annotations according to keywords, in the phase of information retrieval $G 2 A$ shows all the pericopes which present common traits. Thanks to a drop-down menu, the specialist classifies the Arabic rendering of the Greek term or sentence according to keywords like "literal rendering ", "amplification", "omission ", "free rendering", "misunderstanding ", which synthetically classify the annotation associated with the pericopes. On query, the system provides a synoptic vision of the set of the pericopes responding to the type of annotation requested. Thus, G2A offers not only all the usual search functions, but also a tool for evaluating the level of adaptation $v s$ the literalism of a given translation. ${ }^{9}$ 
"Greek into Arabic « has opened new vistas for research on the knowledge transfer between the ancient world and the Muslim and Christian Mediterranean area until the eve of the modern age, thus contributing to creating a general awareness of the common ground of intellectual discourse and rational argument endowed by the activities of generations of scholars that, irrespective of their language and religious allegiance, considered themselves as the heirs of Greek philosophy and science. What is of far-reaching and lasting consequence, and what even today provides a sense of unity among the civilisations emerging from two millennia of intellectual activity around the Mediterranean, is the rise of demonstrative science based on Aristotle's Posterior Analytics as the model for correct reasoning and attainment of the truth. In this, and only in this, one could, in the view of the philosophers, find a safeguard of intellectual authority. Despite contemporary protestations of spiritual identity and intrinsic otherness, we would like to insist on this common ground and this common language, for which rich evidence is provided by the results of our project. 


\section{References}

Badawī, 'Abd al-Raḥmān, Aflūtīn 'inda l-'arab. Plotinus apud Arabes. Theologia Aristotelis et fragmenta quae supersunt (reprint: Cairo, 1966).

Bozzi, Andrea, G2A: A Web Application to study, annotate, and scholarly edit ancient texts and their aligned translations. Part I. General model of the computational philology application, Studia graeco-arabica 3 (2013) 159-171.

Marchi, Simone Part II. Towards a User Manual, Studia graeco-arabica 3 (2013) 173-183.

D’Ancona, Cristina, Greek into Arabic, in: Kate Fleet, Gudrun Krämer, Denis Matringe, John Nawas and Everett Rowson (eds.), Encyclopaedia of Islam, THREE. (First published online: 2016) Retrieved on 2 October 2018: dx.doi.org/10.1163/1573-3912_ei3_COM_27523.

D'Ancona, Cristina, The Theology Attributed to Aristotle: Sources, Structure, Influence, in: Khaled El-Rouayheb and Sabine Schmidtke (eds.), The Oxford Handbook of Islamic Philosophy (Oxford, 2017) 8-29.

D'Ancona, Cristina, Greek Sources in Arabic and Islamic Philosophy, in: Edward N. Zalta (ed.), The Stanford Encyclopedia of Philosophy (Stanford, 2017) Retrieved on 2 October 2018: plato.stanford.edu/archives/win2017/entries/arabic-islamic-greek.

Di Branco, Marco, The >Perfect King r and his Philosophers. Politics, Religion and GraecoArabic Philosophy in Safavid Iran: the Case of the Uthūlüjiya, Studia graeco-arabica 4 (2014) 191-217.

Dieterici, Friedrich, Die sogenannte Theologie des Aristoteles aus arabischen Handschriften zum ersten Mal herausgegeben (Leipzig, 1882, reprint: Amsterdam, 1965).

Endress, Gerhard, Die wissenschaftliche Literatur, in: Helmut Gätje (ed.), Grundriß der Arabischen Philologie II. Literaturwissenschaft (Reichert/Wiesbaden, 1987) 400-530.

Endress, Gerhard, Arnzen, Rüdiger and Arzhanov, Yuri, Griechische Wissenschaft in arabischer Sprache: Ein griechisch-arabisches Fachwörterbuch der internationalen Wissensgesellschaft im klassischen Islam, Studia graeco-arabica 3 (2013) 143-156.

Roeder, Torsten, Alpha into Alif: Schnittstellen zwischen Schriftkunde und Informatik am Beispiel von Unicode im Glossarium Graeco-Arabicum, Studia graeco-arabica 5 (2015) 345-363. 